\title{
The Taxonomic Significance of Leaf Micromorphology in the Genus Melastoma L. (Melastomataceae)
}

(Kesignifikanan Taksonomi Mikromorfologi Daun dalam Genus Melastoma L. (Melastomataceae))

\author{
NOORMA WATI HARON*, NORDIYANAH ANUAR \& RUBASHINY VEERAMOHAN
}

\begin{abstract}
A comparative leaf micromorphological study of Melastoma malabathricum, M. malabathricum var. alba and M. sanguineum (Melastomataceae) was carried out by scanning electron microscope. Characters such as epidermal cell shape, trichomes and stomatal type and distribution were observed. Non-glandular trichomes are present in all species examined. The stomata are all of paracytic type and dispersed randomly over the whole abaxial surface. The patterns of surface sculpturing and outer stomatal rim are unique in all the species examined. Leaf micromorphology has significant taxonomic value in the genus Melastoma and the present study has added some new taxonomic information for the genus Melastoma.
\end{abstract}

Keywords: Melastoma; scanning electron microscope; stomata; taxonomy; trichomes

\section{ABSTRAK}

Suatu kajian perbandingan mikromorfologi daun Melastoma malabathricum, M. malabathricum var. alba dan M. sanguineum (Melastomataceae) telah dijalankan melalui mikroskop elektron imbasan. Ciri-ciri seperti bentuk sel epidermis, jenis serta taburan stomata dan trikom telah diperhatikan. Trikom tak berglanda hadir dalam semua spesies kajian. Stomata adalah jenis parasitik dan tersebar secara rawak pada keseluruhan permukaan abaksial. Corak pada permukaan dan bibir luar stomata adalah unik dalam kesemua spesies. Mikromorfologi daun mempunyai nilai taksonomi yang signifikan dalam genus Melastoma dan kajian ini telah menambah maklumat baru bagi taksonomi genus Melastoma.

Kata kunci: Melastoma; mikroskop elektron imbasan; stomata; taksonomi; trikom

\section{INTRODUCTION}

Melastomataceae is one of the most abundant and diversified groups of pantropical family. It is represented by 4200-4500 species in 166 genera (Renner 1993) with approximately 1000 species predominantly distributed in tropical Asia (Renner et al. 2001). The family is close to Myrtaceae, but the tissues are not aromatic (Corner 1952). Melastoma L., Tibouchina Aubl., Pternandra Jack. and Memecylon L. are among the most common genera in the family occurring in Peninsular Malaysia. They can be found growing in lowland and mountain forests, also on cleared land including the roadside.

In the Southeast Asian region including Malaysia, the genus Melastoma comprises 22 species, two subspecies and three varieties which are classified by the colour of the flower petals - light-pink magenta, dark-purple magenta and white (Rajenderan 2010). The members of Melastomataceae are largely herbs, shrubs and climbers. They can be easily recognized as the leaves are opposite and entire, generally having three prominent longitudinal veins. The leaf-blades of M. malabathricum L are narrow with slightly rough hairy on both surfaces while glabrous for M. sanguineum Sims. On the other hand, the genus Tibouchina resembles Melastoma but the fruits are in the form of dry capsule instead of berry-like with pulpy mass.
Previous micro-characters and morphological studies on Melastomataceae were carried out by Ocampo and Almeda (2013) on the seeds of Miconieae DC. Milanez and Machado (2011) studied the leaf indumentum of Miconieae while Guimaraes et al. (1999) studied the trichomes of Tibouchina. Micromorphological characters of the leaf has been proven to be the most useful and distinctive characters for the separation and delimitation of some species (Haron \& Moore 1996; Nurit-Silva \& Agra 2011). Previous report on the micromorphology of Melastoma species is very scanty. Therefore, it was the aim of the present study to investigate the leaf micromorphological features of some Melastoma species from Peninsular Malaysia.

\section{MATERIALS AND METHODS}

Two species, Melastoma malabathricum and $M$. sanguineum and one variety M. malabathricum var. alba were studied. Fresh specimens were collected from the Rimba Ilmu Botanical Garden and Institute of Biological Sciences Garden, University of Malaya, Kuala Lumpur, Malaysia. Standard procedures were followed for SEM and matured leaves of all the taxa were used in this study. A section of $3 \mathrm{~mm}^{2}$ of the matured leaf were cut 
and soaked in a mixed solution of $8 \%$ Glutaraldehyde and Sorencen's Buffered Phosphate with a ratio 1:1 for $1 \mathrm{~h}$. Using Sorencen's Buffered Phosphate solution and distilled water in a ratio $1: 1$, the specimens were washed for $5 \mathrm{~min}$ before being soaked in a mixed solution of $4 \%$ Osmium and distilled water (1:1) for $14 \mathrm{~h}$ at low temperature $\left(4^{\circ} \mathrm{C}\right)$. Then, the specimens were soaked in methanol from 10 to $100 \%$ concentration for every 15 min in each concentration. Specimens were then soaked in a mixture of $100 \%$ ethanol and $100 \%$ acetone with ratios $3: 1,1: 1$ and $1: 3$ for $20 \mathrm{~min}$, respectively. The leaf specimens were then soaked in $100 \%$ acetone solution for $20 \mathrm{~min}$, repeating them for four times. Next, $\mathrm{CO}_{2}$ liquid was used to flush the solvent from the tissue using Critical Point Drying (CPD) techniques. The dried specimens were then fixed on to double-sided adhesive tape on labelled stubs and mounted by using Conducting Carbon Cement (LEIT-C) to ensure conductive continuity and coated with gold by using BIO-Rod SEM Coating System. The coated specimens were examined under JEOL JSM-7001F Field Scanning Electron Microscope (FESEM).

\section{RESULTS}

Micromorphological features of both adaxial and abaxial leaf surfaces under SEM are shown in Figures 1-5 and tabulated in Table 1. The leaves of all species examined are hypostomatic, and stomata are dispersed randomly over the whole abaxial surface. The stomata are all of paracytic type and either slightly raised above or sunken below the epidermis.

The surface sculpturing may be striate or undulate. Striae can be observed on the adaxial surface of $M$. malabathricum (Figure 1(a)) and M. sanguineum (Figure 1(e)), while M. malabathricum var. alba (Figure 1(c)) has undulate surface sculpturing. Fine striae were clearly observed on the abaxial surface of M. malabathricum and M. sanguineum whereas in M. malabathricum var. alba, poorly-defined striae was observed. In M. malabathricum, striae are oriented in a radiating manner from the outer stomata rim forming a complicated network of striae (Figure 1(b)). M. malabathricum var. alba (Figure 1(d)) showed a rather smooth surface at some distance from the outer stomata rim before projections appeared forming

TABLE 1. Leaf epidermal characters of Melastoma species

\begin{tabular}{|c|c|c|c|c|}
\hline \multicolumn{2}{|r|}{ Characters } & \multirow{2}{*}{ M. malabathricum L. } & \multirow{2}{*}{ M. malabathricum L. var. alba } & \multirow[t]{2}{*}{ M. sanguineum Sims. } \\
\hline (a) & Epidermal cells & & & \\
\hline & (i) Shape & Irregular & Irregular & Polygonal \\
\hline & (ii) Adaxial surface sculpturing & Striate & Undulate & Striate \\
\hline & (iii) Abaxial surface sculpturing & Fine striate & Poorly-defined striate & Fine striate \\
\hline \multirow[t]{3}{*}{ (b) } & Epicuticular wax & & & \\
\hline & (i) Adaxial surface & Absent & Absent & Present \\
\hline & (ii) Abaxial surface & Absent & Absent & Absent \\
\hline \multirow[t]{7}{*}{ (c) } & Stomata & & & \\
\hline & (i) Type & Paracytic & Paracytic & Paracytic \\
\hline & (ii) Shape & Elliptic & Elliptic & Elliptic \\
\hline & (iii) Length $(\mu \mathrm{m})$ & 4.86 & 5.3 & 5.57 \\
\hline & (iv) Width $(\mu \mathrm{m})$ & 1.48 & 1.8 & 1.21 \\
\hline & (v) Outer stomatal rim & Poorly-developed & Poorly-developed & Well-defined \\
\hline & (vi) Stomata & Slightly raised & Slightly raised & Sunken \\
\hline \multirow[t]{12}{*}{ (d) } & Trichomes & & & \\
\hline & (i) Type & $\begin{array}{l}\text { Non-glandular, } \\
\text { protuberance }\end{array}$ & $\begin{array}{l}\text { Non-glandular, } \\
\text { protuberance }\end{array}$ & $\begin{array}{l}\text { Non-glandular, } \\
\text { protuberance }\end{array}$ \\
\hline & (ii) Distribution & & & \\
\hline & - on adaxial surface & Sparsely distributed & Evenly distributed & Absent \\
\hline & - $\quad$ on abaxial surface & Densely distributed & Densely distributed & Sparsely distributed \\
\hline & - $\quad$ on margin & Present & Present & Present \\
\hline & - $\quad$ on leaf apex & & & \\
\hline & (abaxial) & Scaly & Scaly & Scaly \\
\hline & (adaxial) & Pointing towards margin & Pointing towards apex & Pointing towards apex \\
\hline & - $\quad$ on leaf base & & & \\
\hline & (abaxial) & Scaly & Scaly & Scaly \\
\hline & (adaxial) & Scaly & Scaly & Long, thin \\
\hline
\end{tabular}



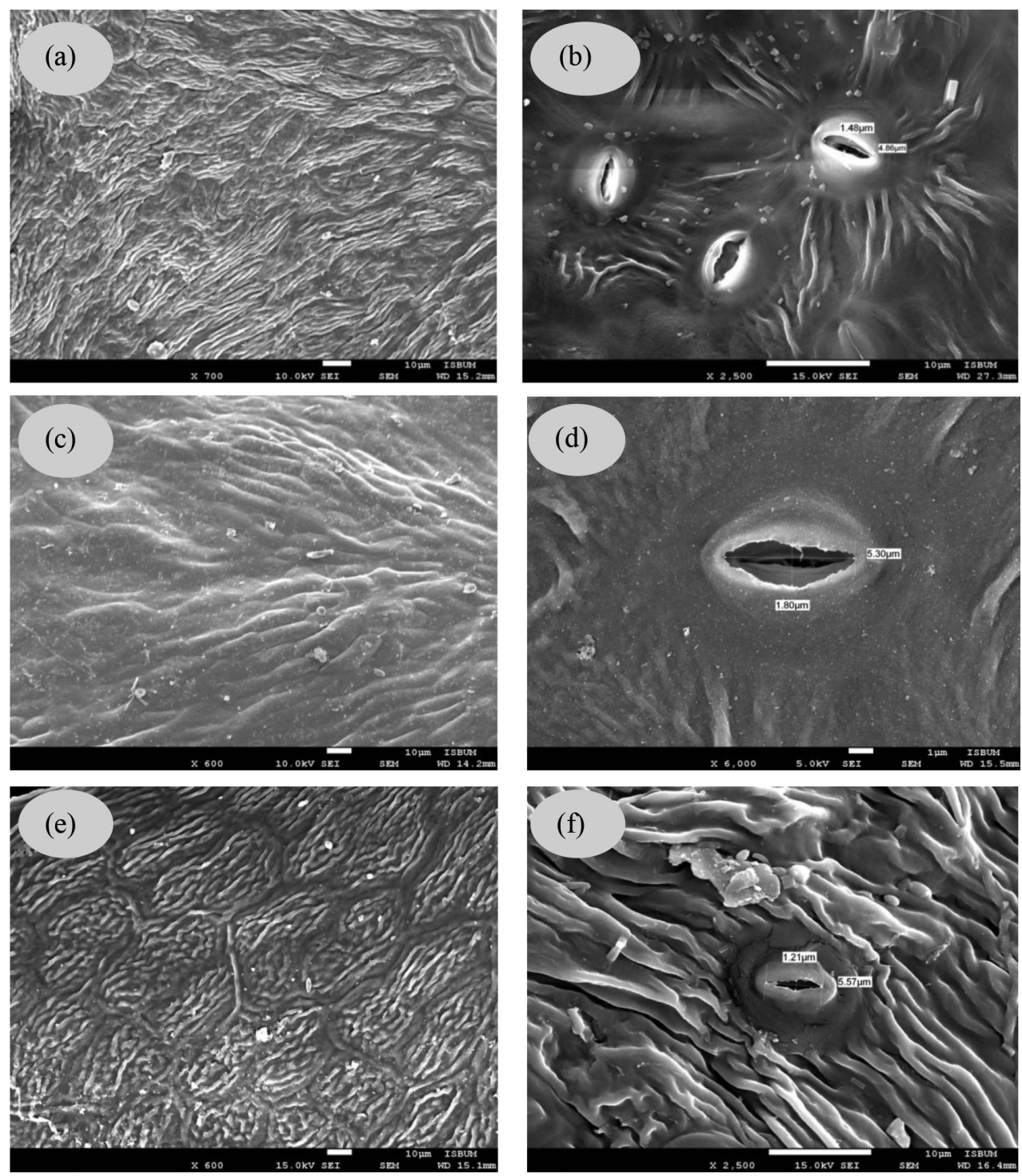

FIGURE 1. SEMs of adaxial and abaxial surfaces of leaf showing the surface sculpturing and the types of stomata (a) M. malabathricum, adaxial surface showing striate surface sculpturing,(b) M. malabathricum, abaxial surface showing fine striate projecting outwards from the slightly raised stomata, (c) M. malabathricum var. alba, adaxial surface showing undulate surface sculpturing, (d) M. malabathricum var. alba, abaxial surface showing poorly-defined striate sculpturing with slightly raised stomata, (e) M. sanguineum, adaxial surface showing isodiametric, striate sculpturing and (f) M. sanguineum, abaxial surface showing coarse, fine striate sculpturing with sunken stomata

a network of poorly-defined striae while $M$. sanguineum (Figure 1(f)) has coarse, well-defined striate surface. The striae are oriented in a manner of forming a network of densely continuous striae. In M. sanguineum, the adaxial epidermis cells are more or less polygonal in shape, whereas the abaxial epidermis has an irregular cell shape (Figures 1(e) and 1(f)). However, both adaxial and abaxial epidermis of M. malabathricum (Figure 1(a) and 1(b)) and M. malabathricum var. alba (Figure 1(c) and 1(d)) have irregular cell shapes.

The stomata of M. sanguineum (Figure 1(f)) were found to be longer than M. malabathricum (Figure 1(b)) and M. malabathricum var. alba (Figure $1(\mathrm{~d})$ ) where the stomata measurement was $5.57 \mu \mathrm{m}$ in length and 1.21 $\mu \mathrm{m}$ in width and sunken below the epidermis. In $M$. malabathricum and its variety, M. malabathricum var. $a l b a$, the stomata are slightly raised above the epidermis. The outer stomatal rim is either poorly-developed or well-defined. M. malabathricum and M. malabathricum var. alba have poorly-developed outer stomatal rim while M. sanguineum has well-defined outer stomatal rim. In all the species examined, the adaxial epidermis showed two types of cell shape i.e. irregular and polygonal.

SEM analyses confirmed the presence of non-glandular trichomes in all the species examined and they varied in structure on both surfaces (Figure 2). The epidermal trichomes have protuberance surface along their length. Protuberances are more or less pronounced, blunt and directed towards the trichome tip. Short, sparsely distributed trichomes were present on the whole adaxial 

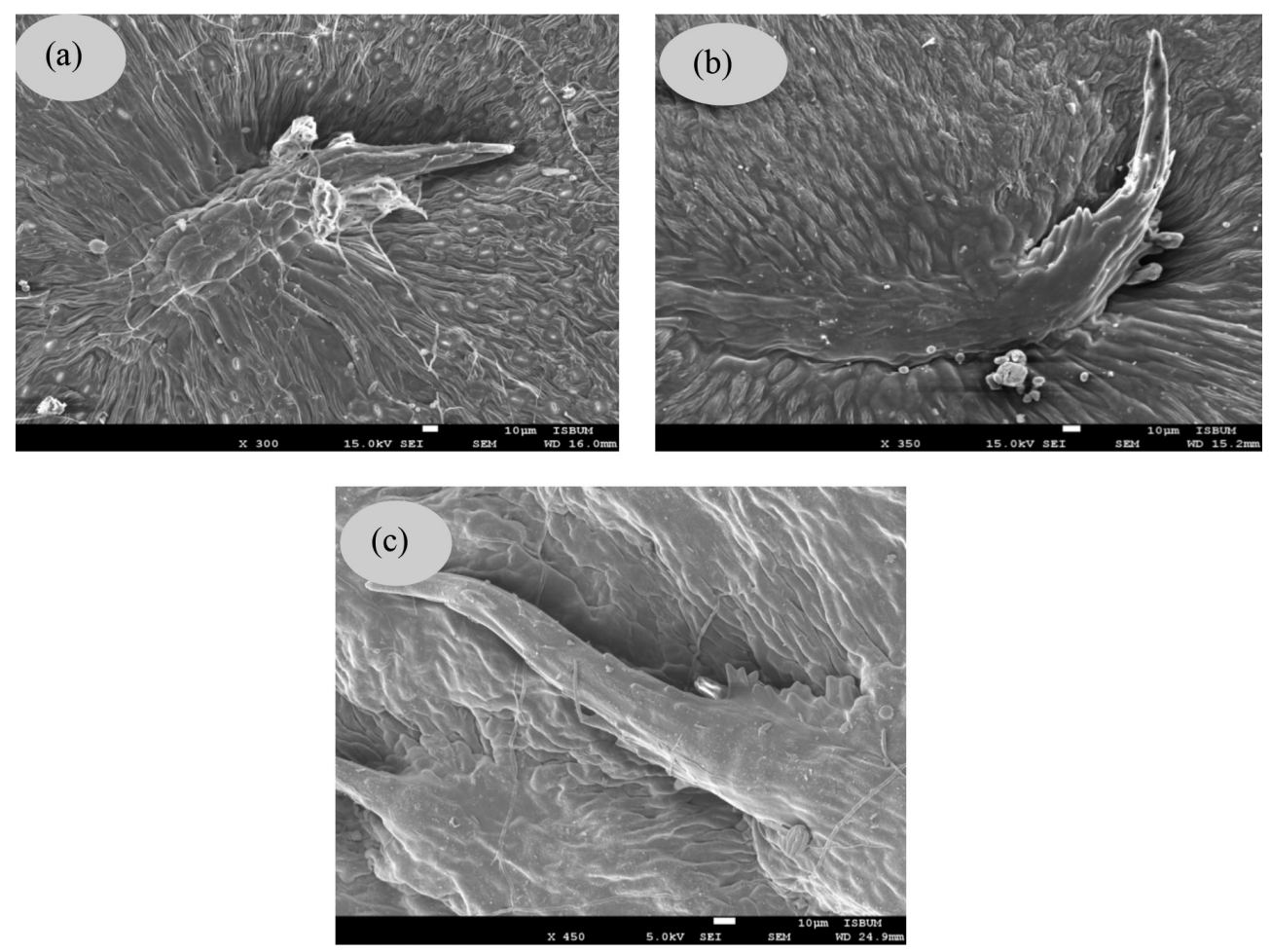

FIGURE 2. SEMs showing protuberance, non-glandular trichomes in (a) M. malabathricum, (b) M. malabathricum var. alba and (c) M. sanguineum

surface of M. malabathricum (Figure 3(a)) while in $M$. malabathricum var. alba, they were evenly distributed (Figure 3(c)). In M. malabathricum, the abaxial surface of lamina was covered with short trichomes while longer, thin trichomes were found on the midrib (Figure 3(b)). In $M$. malabathricum var. alba, the abaxial surface was covered with both short and long trichomes on the midrib and lamina (Figure 3(d)). They were more densely distributed on the leaf base (Figure 4(a) and 4(c)) than on the lamina and apex. Scaly trichomes were present along the abaxial leaf base and leaf apex of M. malabathricum (Figures 4(b) and 5(b)) and M. malabathricum var. alba (Figures 4(d) and 5(d)). Trichomes on adaxial epidermal leaf apex in M. malabathricum protrude out the margin (Figure 5(a)) whereas in M. malabathricum var. alba (Figure 5(c)) the trichomes protrude towards the apex. The margin appeared to have longer trichomes than on the lamina.

Under SEM, M. malabathricum and M. malabathricum var. alba have pointed leaf apices while $M$. sanguineum has blunt leaf apex. In $M$. sanguineum, trichomes were absent on adaxial leaf surfaces (Figure 3(e)). Otherwise, they were found to be sparsely distributed on the abaxial leaf surface, leaf base and leaf apex in the form of short trichomes (Figures 3(f), 4(f) and 5(f)). The adaxial leaf base and margin appeared to have long trichomes (Figure 4(e)). Epicuticular wax was found to cover the whole adaxial leaf epidermal including trichomes in the form of flakes in M. sanguineum (Figure 5(e)). Wax deposition was not observed on both leaf surfaces of M. malabathricum and M. malabathricum var. alba.

\section{DISCUSSION}

Examination of the leaf surface showed great variations in the surface sculpturing patterns. The surface sculpturings observed varies from smooth to striae. Striate surface sculpturing was observed in M. malabathricum, $M$. malabathricum var. alba and M. sanguineum but there are some differences in their features where M. sanguineum has very fine and compact striae compared to the former two species. Meanwhile, striation on the abaxial surface of M. malabathricum is more conspicuous compared to M. malabathricum var. alba. These significant patterns of surface sculpturing might be useful in distinguishing the species in the genus Melastoma.

The epidermal cells of the leaf surfaces in the species examined are polygonal or irregular in shape which is agreeable with the study of some Melastoma species from Taiwan by Hsiao (2008). In M. sanguineum, epicuticular wax occurs on the leaf surfaces in the form of flakes. Epicuticular wax was absent in M. malabathricum and M. malabathricum var. alba. Marques et al. (2000) suggested that the increase in the thickness of epicuticular wax may increase the protection against light irradiation. Another studies reported that a thicker epicuticular wax presumably led to reduced water loss from the plant (AliAhmad et al. 1998).

From this study, it was noted that stomata are generally elliptical in shape. M. malabathricum, $M$. malabathricum var. alba and $M$. sanguineum possessed paracytic stomata. Beside the paracytic type, anomocytic, diacytic, polocytic and staurocytic types of stomata 

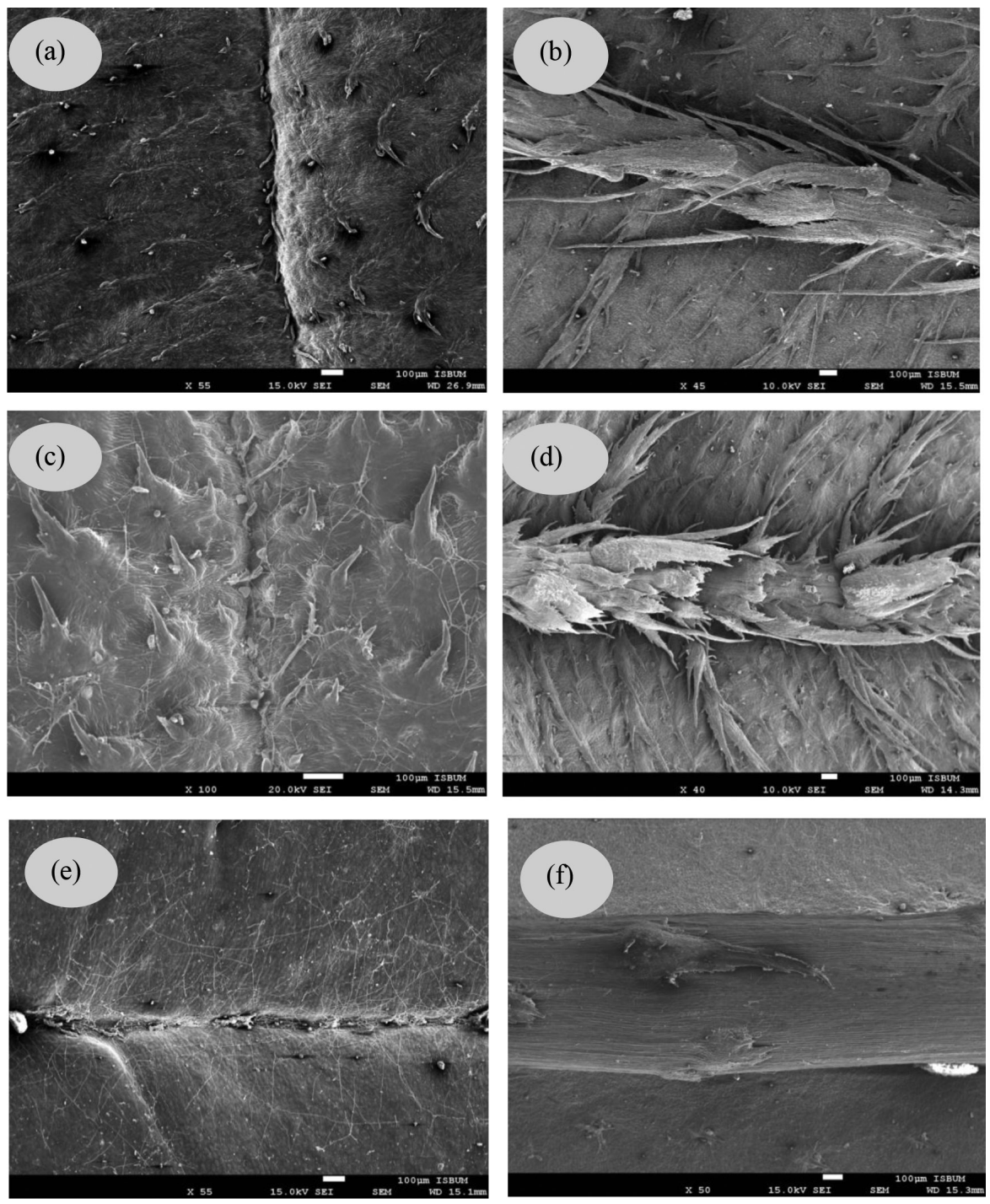

FIGURE 3. SEMs of adaxial and abaxial surfaces of leaf showing the distribution of trichomes (a) M.malabathricum, adaxial surface with sparsely distributed trichomes, (b) M. malabathricum, abaxial surface covered with short trichomes on lamina together with longer, thin trichomes on midrib, (c) M. malabathricum var. alba, adaxial surface with evenly distributed trichomes, (d) M. malabathricum var. alba, abaxial surface covered with both short and long trichomes on midrib and lamina, (e) M. sanguineum, adaxial surface showing the absence of trichome and (f) M. sanguineum, abaxial surface poorly distributed with trichomes

have been recorded by Hsiao (2008) in 11 genera of Melastomataceae from Taiwan. Meanwhile, Abere et al. (2009) reported anomocytic stomata in Dissotis rotundifolia triana (Melastomataceae). Significant comparison of stomatal size between abaxial and adaxial leaf surfaces has been reported by Zoric et al. (2009). They observed that adaxial epidermis has smaller stomata size then abaxial epidermis. In the present study, the stomata of all the species examined are hypostomatic. Therefore, the stomatal size between both adaxial and abaxial leaf surfaces of the species cannot be compared.

It has been noted that the morphology of stomata could be among the most distinctive character in some species of Melastomataceae. Mouriri morleyii R. Goldenb. is distinguished from the other species in the genus by its large stomatal crypts (Goldenberg et al. 2013). In the present study, $M$. sanguineum can be easily distinguished from M. malabathricum and $M$. malabathricum var. alba as its outer stomatal rim is well-defined. On the other hand, stomatal patterning could also be environmental responsive. Under drought and salt stresses, abnormal stomatal patterning known as 'stomatal clustering' is induced in the leaf epidermal of many plant families such as Vicia faba L. (Leguminosae), Arabidopsis thaliana L. (Brassicaceae) and Cinnamomum camphora L. J. Presl (Lauraceae) (Gan et al. 2010).

Micromorphologically, M. malabathricum, M. malabathricum var. alba and $M$. sanguineum shared the same types of trichome where all these species possess non-glandular trichomes, differing in their patterns of distribution. In all the species examined, trichomes were densely distributed on the leaf base 

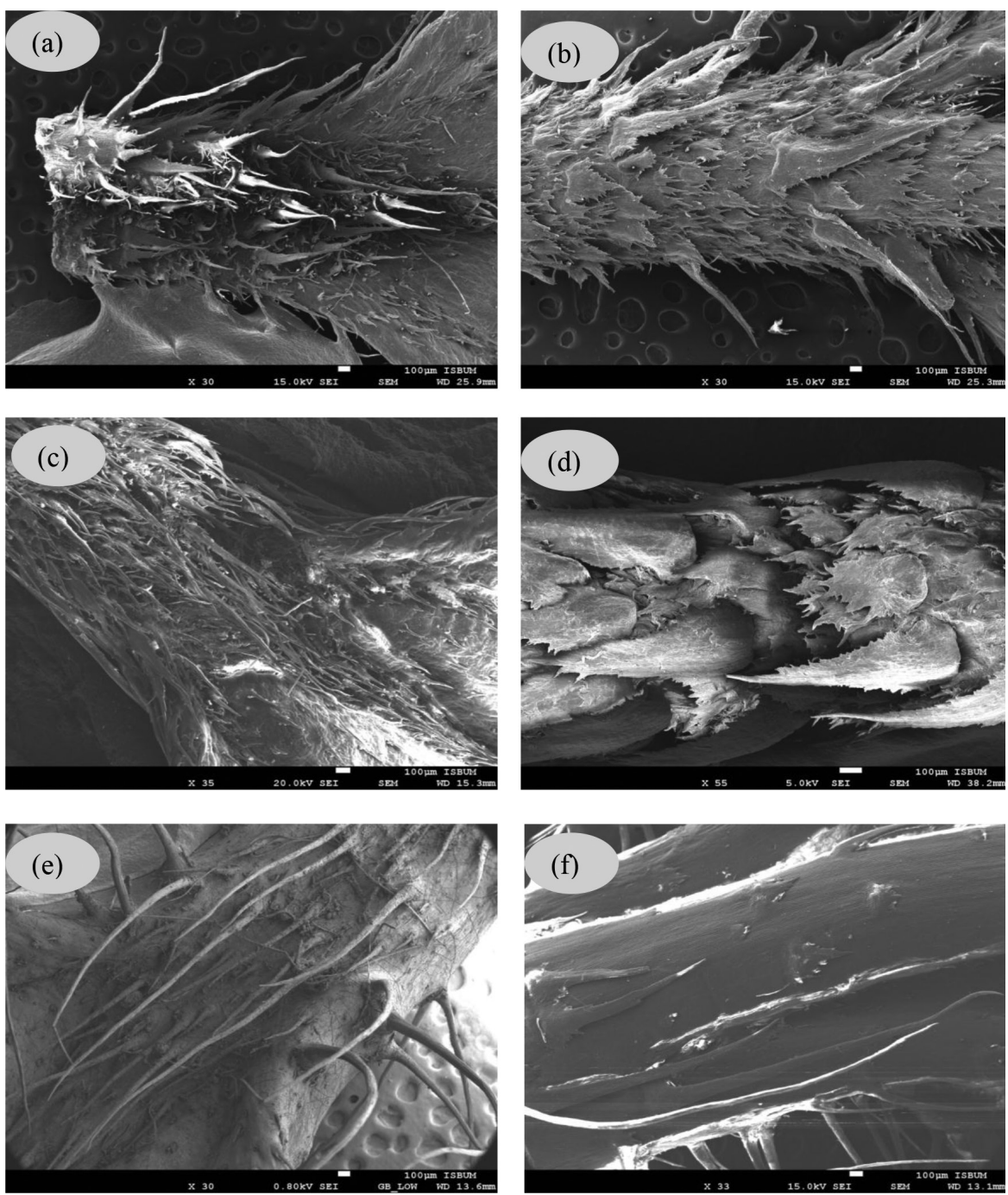

FIGURE 4. SEMs showing adaxial and abaxial of leaf base of Melastoma (a) M. malabathricum, adaxial surface is covered with trichomes, (b) M. malabathricum, abaxial surface is very densely covered with scaly trichomes, (c) and (d) M. malabathricum var. alba, (adaxial and abaxial surface) densely covered with trichomes, (e) M. sanguineum, adaxial surface is covered with long, trichomes and (f) M. sanguineum, abaxial surface showing sparsely distributed trichomes

compared to the lamina. M. sanguineum demonstrated distinguishable characters among the species examined as the trichomes were not observed on the adaxial surface. Trichomes were only found on the leaf margin in $M$. sanguineum while in M. malabathricum and $M$. malabathricum var. alba, they were densely distributed on both sides. Chen et al. (2013) reported that among six species of Melastoma investigated in China; $M$. intermedium Dunn, M. normale D. Don, M. affine D. Don, $M$. candidum D. Don and $M$. sanguineum have trichomes on both the adaxial and abaxial surfaces of the leaves except $M$. dodecandrum. However, the present investigation showed that trichome was absent on the adaxial leaf surface of $M$. sanguineum. Hence, it can be postulated that the localization of the trichomes on the leaf surface varies greatly between species. This observation has also been pointed out by Guimaraes et al. (1999) in several species of Tibouchina section Pleroma
(Melastomataceae) and Elzbieta and Chernetskyy (2005) in the species of Kalanchoe (Crassulaceae). Xiang et al. (2010) also found that the morphology and distribution of trichomes have valuable taxonomic significance at species level in Chelonopsis (Lamiaceae). Trichomes have a defense mechanism to detect pathogen infection (War et al.2012). Trichomes also increased the tolerance to drought by reducing absorbance of solar radiation and facilitating condensation of air moisture onto the plant surface as reported by Dalin et al. (2008). The absence of trichomes on the adaxial leaf surface of $M$. sanguineum may be compensated by the epicuticular wax on the whole adaxial leaf surface. Therefore, trichome micromorphology and distribution are found to be useful in delimitation of species in the genus Melastoma. However, further studies are recommended to determine whether these features are influenced by environmental factors or may be under genetic control. 

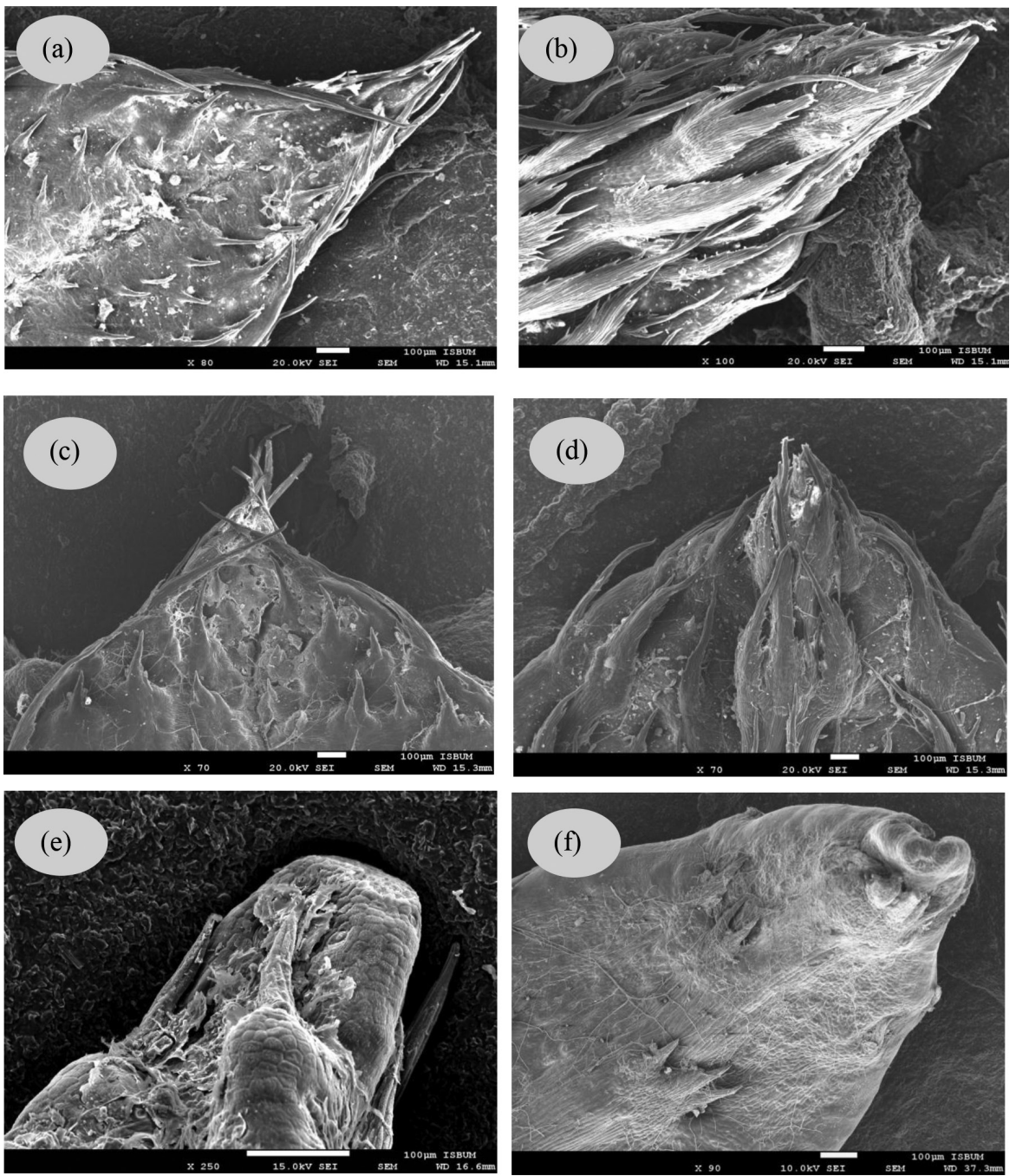

FIGURE 5. SEMs showing adaxial and abaxial leaf apex of Melastoma (a) and (b) M. malabathricum, (adaxial and abaxial surfaces), trichomes densely present on leaf margin and acuminate apex, (c) and (d) M. malabathricum var. alba (adaxial and abaxial surfaces), trichomes densely present on leaf margin and acute apex, (e) M. sanguineum, adaxial surface is covered with wax. Apex is blunt with trichomes only on the margin and (f) M. sanguineum, abaxial surface showing sparsely distributed short trichomes

\section{CONCLUSION}

Leaf micromorphology has significant taxonomic value in the genus Melastoma. Surface sculpturing patterns, distribution of trichomes and outer stomatal rims were significant features in characterizing the species. The present study has added some new taxonomic characters in distinguishing Melastoma species.

\section{ACKNOWLEDGEMENTS}

The authors would like to thank University of Malaya for the financial support (Grant: FL001C-13BIO) and the facilities provided.

\section{REFERENCES}

Abere, T.A., Onwukaeme, D.N. \& Eboka, C.J. 2009. Pharmacognostic evaluation of the leaves of Dissotis rotundifolia Triana (Melastomataceae). African Journal of Biotechnology 8: 113-115.
Ali-Ahmad, M., Hughies, H.G. \& Safadi, F. 1998. Studies on stomatal function, epicuticular wax and stem-root transition region of polyethylene glycol-treated and nontreated in vitro grape plantlets. In Vitro Cellular and Developmental Biology 34: 1-7.

Chen, J.L., Lan, S.R., Wu, S.S., Yang, H., Wu, H.C. \& Peng, D.H. 2013. Leaf surface characteristics of 6 species of Melastoma L. and their taxonomic significance. Journal of Fujian College of Forestry 2: 106-112.

Corner, E.J.H. 1952. Wayside Trees of Malaya. Singapore: Government Printing Office.

Dalin, P., Agren, J., Bjorkman, C., Huttunen, P. \& Karkkainen, K. 2008. Leaf trichome formation and plant resistance to herbivory. In Induced Plant Resistance to Herbivory, edited by Schaller, A. Netherlands: Springer. pp. 89-105.

Elzbieta, W.C. \& Chernetskyy, M. 2005. Structure of trichomes from the surface of leaves of some species of Kalanchoe Adans. Acta Biologica Cracoviensia 47: 15-22.

Gan, Y., Zhou, L., Shen, Z.J., Shen, Z.X., Zhang, Y.Q. \& Wang, G.X. 2010. Stomatal clustering, a new marker for environmental perception and adaptation in terrestrial plants. Botanical Studies 51: 325-336. 
Goldenberg, R., Meirelles, J. \& Amano, E. 2013. Mouriri morleyii sp. nov. (Melastomataceae) from Brazil, with notes on its foliar stomatal crypts. Nordic Journal of Botany 31: 321-325.

Guimaraes, P.J.F., Rana, N.T. \& Martins, A.B. 1999. Morphology of trichomes in Tibouchina section Pleroma (D.Don) Cogn. (Melastomataceae). Brazilian Archives of Biology and Technology 42: 485-493.

Haron, N.W. \& Moore, D.M. 1996. The taxonomic significance of leaf micromorphology in the genus Eugenia L. (Myrtaceae). Botanical Journal of the Linnean Society 120: 265-277.

Hsiao, P.M. 2008. A study on leaf morphology of Melastomataceae in Taiwan. Masters Thesis. National Sun Yat-sen University (unpublished).

Marques, A.R., Garcia, Q.S., Rezzende, J.L.P. \& Fernandes, G.W. 2000. Variations in leaf characteristics of two species of Miconia in the Brazilian cerrado under different light intensities. Tropical Ecology 41: 47-60.

Milanez, C.R.D. \& Machado, S.R. 2011. SEM studies on the leaf indumentum of six Melastomataceae species from Brazilian Cerrado. Rodriguésia 62: 203-212.

Nurit-Silva, K. \& Agra, D.F. 2011. Leaf epidermal characters of Solanum sect. Polytrichum (Solanaceae) as taxonomic evidence. Microscopy Research Technology 74: 1186-1191.

Ocampo, G. \& Almeda, F. 2013. Seed diversity in the Miconieae (Melastomataceae): Morphological characterization and phenetic relationships. Phytotaxa 80: 1-129.

Rajenderan, M.T. 2010. Ethno medicinal uses and antimicrobial properties of Melastoma malabathricum. SEGi Review 3: 34-44.
Renner, S.S. 1993. Phylogeny and classification of the Melastomataceae and Memecylaceae. Nordic Journal of Botany 13: 519-540.

Renner, S.S., Clausing, G. \& Meyer, K. 2001. Historical biogeography of Melastomataceae: The roles of tertiary migration and long-distance dispersal. American Journal of Botany 88: 1290-1300.

War, A.R., Paulraj, M.G. \& Sharma, H.C. 2012. Mechanisms of plant defense against insect herbivores. Plant Signaling and Behavior 7: 1306-1320.

Xiang, C.L., Dong, Z.H., Peng, H. \& Liu, Z.W. 2010. Trichome micromorphology of the East Asiatic genus Chelonopsis (Lamiaceae) and its systematic implications. Flora 205: 434-441.

Zoric, L., Merkulov, L., Lukovic, J., Boza, P. \& Polic, D. 2009. Leaf epidermal characteristics of Trifolium L. species from Serbia and Montenegro. Flora 204: 198-209.

Institute of Biological Sciences

University of Malaya

50603 Kuala Lumpur

Malaysia

*Corresponding author; email: noorma@um.edu.my

Received: 10 June 2014

Accepted: 9 January 2015 